\title{
Safety and Microbiological Quality
}

\author{
Fabienne Remize ${ }^{1, *(1)}$ and Didier Montet ${ }^{2}$ \\ 1 UMR QualiSud, Université de La Réunion, CIRAD, Université Montpellier, Montpellier SupAgro, Université \\ d'Avignon et des Pays de Vaucluse, 97490 Sainte Clotilde, France \\ 2 UMR QualiSud, CIRAD, Université Montpellier, Montpellier SupAgro, Université d'Avignon et des Pays de \\ Vaucluse, Université de La Réunion, 34398 Montpellier CEDEX 5, France; didier.montet@cirad.fr \\ * Correspondence: fabienne.remize@univ-reunion.fr
}

Received: 12 June 2019; Accepted: 18 June 2019; Published: 19 June 2019

check for updates

Food fermentation aims, primarily, to increase the shelf life of perishable foodstuffs. It is characterized by an extremely large diversity of raw materials, and an even wider range of fermented products, differing in their form, taste, color, or recipe [1]. The success of shelf life increase relies on acidification or ethanol production. Detoxification of endogenous compounds and increase in digestibility are other health-related benefits of fermentation. Additionally, in many parts of the word, as in Asia, fermented foods have a traditional role in overcoming food and nutritional insecurity [2].

Safety concerns cover the control of growth and persistence of foodborne pathogens, and the presence of toxic compounds, formed over fermentation or present in raw materials. For instance, in Italy, alcoholic fermentation during winemaking was affected by upstream plant treatments, i.e., pesticides used to fight Plasmopara viticola, the causal oomycete agent of grapevine downy mildew [3]. Active compounds used in commercial pesticide preparation, and possibly compounds used as excipients, negatively affect both Saccharomyces and non-Saccharomyces yeast growth. A careful examination of the effect on pro-technological microorganisms of pesticides is recommended.

Foodborne pathogen infections and diarrhea can be prevented with the use of probiotic cultures $[4,5]$. Bifidobacterium spp. is one of the most frequently used probiotic bacteria. Probiotic effect requires that the bacteria can survive and grow in the food matrix used for probiotic delivery. Hence, examination of Bifidobacterium strain viability in media is a key component for probiotic development [6]. Similarly, Enterococcus faecium and Enterococcus faecalis are frequently isolated from fermented foods, for instance table olives [7]. In addition, they produce bile salt hydrolases and are resistant to low $\mathrm{pH}$, and are therefore able to stay alive until they reach the intestinal tract. However, these two Gram-positive lactic acid bacteria have been implicated in infectious diseases and a careful examination of antibiotic susceptibility, virulence, and absence of hemolysis and cytotoxicity is required before their use as starters and possibly probiotics [8-10].

The use of fruit juice to deliver probiotics is an advantage regarding lactose intolerant people and, for economic reasons, in developing countries. An innovative strategy for the prevention of shigellosis, which persists endemically and causes epidemics in tropical countries, is to enhance the capacity of probiotics to suppress the growth of different species of Shigella. This approach was applied with different fruit matrix, and the impact of processing and the storage of the juice on the efficacy of probiotics was examined [11].

Microbiological quality of fermented foods includes fermentation process reliability, which impacts sensory quality and shelf life. Process reliability depends on starter fitness and its growth properties in the food matrix. Predictive growth models can be used to determine the optimal conditions on use of single or mixed lactic acid bacterium cultures [12]. In addition, microbiological quality of fermented foods and beverages is closely connected to nutritional quality. For instance, the fungus Mucor circinelloides is a promising oil cell factory, producing medium-chain fatty acids (MCFA). Adjustment of cultivation conditions can improve biomass, total fatty acid, and MCFA contents [13]. 
The development of new lactic fermented beverages from non-dairy sources is of increasing interest because of the combined advantages of plant nutritional properties and benefits from lactic fermentation [14,15]. Tiger nut tubers, Cyperus esculentus, are of particular interest because of their richness in lipid and dietary fiber, close to those of nuts, a high content of starch, like in other tubers, and high levels of phosphorus, calcium, and phenolic compounds [16]. The development of fermented or probiotic beverages from tiger nuts must carefully select a tailored bacterial cocktail able to dominate undesirable endogenous flora (either foodborne pathogens or spoilage microorganisms), preserve bioactive compounds, and result in a well-accepted beverage. The nutritional properties of fermented papaya have been extensively studied over the last decade. At present, a corpus of studies shows the cellular protective effects of fermented papaya and its ability to reduce oxidative stress, and thinking of the use of that product for disease prevention and management through a holistic approach has been reviewed $[17,18]$.

All together, the articles of this special issue provide a broad view of the safety and microbiological quality determining factors in fermented foods. The interconnection of starter properties and probiotic effect expectations are focused on. A common point of the articles published in this special issue is their involvement towards better resource management and increasing food and nutritional security, especially in developing countries.

Conflicts of Interest: The authors declare no conflict of interest.

\section{References}

1. Ray, R.C.; Montet, D. Microorganisms and Fermentation of Traditional Foods; CRC Press: Boca Raton, FL, USA, 2015; ISBN 9781482223088.

2. Kumar Anal, A. Quality Ingredients and Safety Concerns for Traditional Fermented Foods and Beverages from Asia: A Review. Fermentation 2019, 5, 8. [CrossRef]

3. Russo, P.; Berbegal, C.; De Ceglie, C.; Grieco, F.; Spano, G.; Capozzi, V.; Russo, P.; Berbegal, C.; De Ceglie, C.; Grieco, F; et al. Pesticide Residues and Stuck Fermentation in Wine: New Evidences Indicate the Urgent Need of Tailored Regulations. Fermentation 2019, 5, 23. [CrossRef]

4. Ranadheera, C.; Vidanarachchi, J.; Rocha, R.; Cruz, A.; Ajlouni, S.; Ranadheera, C.S.; Vidanarachchi, J.K.; Rocha, R.S.; Cruz, A.G.; Ajlouni, S. Probiotic Delivery through Fermentation: Dairy vs. Non-Dairy Beverages. Fermentation 2017, 3, 67. [CrossRef]

5. Hill, C.; Guarner, F.; Reid, G.; Gibson, G.R.; Merenstein, D.J.; Pot, B.; Morelli, L.; Canani, R.B.; Flint, H.J.; Salminen, S.; et al. The International Scientific Association for Probiotics and Prebiotics consensus statement on the scope and appropriate use of the term probiotic. Nat. Rev. Gastroenterol. Hepatol. 2014, 11, 506-514. [CrossRef] [PubMed]

6. Matejčeková, Z.; Vlková, E.; Liptáková, D.; Valík, L'. Preliminary Screening of Growth and Viability of 10 Strains of Bifidobacterium sp.: Effect of Media Composition. Fermentation 2019, 5, 38. [CrossRef]

7. Anagnostopoulos, D.; Bozoudi, D.; Tsaltas, D.; Anagnostopoulos, D.A.; Bozoudi, D.; Tsaltas, D. Enterococci Isolated from Cypriot Green Table Olives as a New Source of Technological and Probiotic Properties. Fermentation 2018, 4, 48. [CrossRef]

8. Foulquié Moreno, M.R.; Sarantinopoulos, P.; Tsakalidou, E.; De Vuyst, L. The role and application of enterococci in food and health. Int. J. Food Microbiol. 2006, 106, 1-24. [CrossRef] [PubMed]

9. Baccouri, O.; Boukerb, A.M.; Farhat, L.B.; Zébré, A.; Zimmermann, K.; Domann, E.; Cambronel, M.; Barreau, M.; Maillot, O.; Rincé, I.; et al. Probiotic Potential and Safety Evaluation of Enterococcus faecalis OB14 and OB15, Isolated from Traditional Tunisian Testouri Cheese and Rigouta, Using Physiological and Genomic Analysis. Front. Microbiol. 2019, 10, 881. [CrossRef] [PubMed]

10. Ayala, D.I.; Cook, P.W.; Franco, J.G.; Bugarel, M.; Kottapalli, K.R.; Loneragan, G.H.; Brashears, M.M.; Nightingale, K.K. A Systematic Approach to Identify and Characterize the Effectiveness and Safety of Novel Probiotic Strains to Control Foodborne Pathogens. Front. Microbiol. 2019, 10, 1108. [CrossRef] [PubMed]

11. Sireswar, S.; Montet, D.; Dey, G.; Sireswar, S.; Montet, D.; Dey, G. Principal Component Analysis for Clustering Probiotic-Fortified Beverage Matrices Efficient in Elimination of Shigella sp. Fermentation 2018, 4, 34. [CrossRef] 
12. Medved'ová, A.; Šipošová, P.; Mančušková, T.; Valík, L'. The Effect of Salt and Temperature on the Growth of Fresco Culture. Fermentation 2018, 5, 2. [CrossRef]

13. Hussain, S.A.; Nazir, Y.; Hameed, A.; Yang, W.; Mustafa, K.; Song, Y.; Hussain, S.A.; Nazir, Y.; Hameed, A.; Yang, W.; et al. Optimization of Diverse Carbon Sources and Cultivation Conditions for Enhanced Growth and Lipid and Medium-Chain Fatty Acid (MCFA) Production by Mucor circinelloides. Fermentation 2019, 5, 35. [CrossRef]

14. Fessard, A.; Kapoor, A.; Patche, J.; Assemat, S.; Hoarau, M.; Bourdon, E.; Bahorun, T.; Remize, F. Lactic fermentation as an efficient tool to enhance the antioxidant activity of tropical fruit juices and teas. Microorganisms 2017, 5, 23. [CrossRef] [PubMed]

15. Septembre-Malaterre, A.; Remize, F.; Poucheret, P. Fruits and vegetables, as a source of nutritional compounds and phytochemicals: Changes in bioactive compounds during lactic fermentation. Food Res. Int. 2017. [CrossRef] [PubMed]

16. Roselló-Soto, E.; Garcia, C.; Fessard, A.; Barba, F.; Munekata, P.; Lorenzo, J.; Remize, F.; Roselló-Soto, E.; Garcia, C.; Fessard, A.; et al. Nutritional and Microbiological Quality of Tiger Nut Tubers (Cyperus esculentus), Derived Plant-Based and Lactic Fermented Beverages. Fermentation 2019, 5, 3. [CrossRef]

17. Somanah, J.; Putteeraj, M.; Aruoma, O.; Bahorun, T.; Somanah, J.; Putteeraj, M.; Aruoma, O.I.; Bahorun, T. Discovering the Health Promoting Potential of Fermented Papaya Preparation-Its Future Perspectives for the Dietary Management of Oxidative Stress During Diabetes. Fermentation 2018, 4, 83. [CrossRef]

18. Somanah, J.; Bourdon, E.; Rondeau, P.; Bahorun, T.; Aruoma, O.I. Relationship between fermented papaya preparation supplementation, erythrocyte integrity and antioxidant status in pre-diabetics. Food Chem. Toxicol. 2014, 65, 12-17. [CrossRef] [PubMed]

(C) 2019 by the authors. Licensee MDPI, Basel, Switzerland. This article is an open access article distributed under the terms and conditions of the Creative Commons Attribution (CC BY) license (http://creativecommons.org/licenses/by/4.0/). 